\title{
FIGURES OF SPEECH IN SURAH AR-RAHMAN
}

\author{
Ainun Rida Nasution \\ Sumarsih \\ Amrin Saragih
}

Diterima Desember 2017; Disetujui Februari 2018; Dipublikasikan April 2018

\begin{abstract}
The aims of this study were to find out the kinds of figures of speech in surah Ar-Rahman, and to investigate realization of figures of speech in surah Ar-Rahman. The research was conducted by using qualitative descriptive design. The data of this study were 78 verses of surah Ar -Rahman. Besides, Miles, Huberman's, and Saldana's analysis applied in this study. In addition, Keraf theory (2004) was used in this study to find out kinds of figures of speech in surah Ar-Rahman, and Arp and Perrine theory (1963) was applied to investigate realization of figures of speech in surah Ar-rahman. The results of this study were (1) There were 10 kinds figures of speech in surah Ar-Rahman namely 3 Simile 2 Personifications 1 Apophasis 31 Repetition 2 Paralellism 1 Apostrophe 2 Pleonasm 1 Prolepsis 1 Antonomasia 1 Tautology (2) In realization figures of speech in surah Ar-rahman . ways in figures of speech in surah Ar-Rahman namely explicitly, comparing things, noun, repetition, synonym, denial, redundancy, substitution, and future. (3)The reason used figures of speech in surah Ar-rahman namely faith, laws of justice, man and jinn, hell and favors heaven.
\end{abstract}

Key words: Figures of Speech, Ar-Rahman, Surah

How to Cite: Ainun Rida Nasution (2018).FigureofSpeech in Surah Ar-Rahman .JurnalLinguistikTerapanPascasarjanaUnimed, 15 (2): 1-7

*Corresponding author:

ISSN 2407-7410 


\section{INTRODUCTION}

The teachings of Al- Qur'an are universal, addressed to all people throughout the world regardless of their creed and color. They enlighten man's soul, purify his morals, condemn all wrongs, order good deeds and call for the establishment of justice and fraternity through obeying Allah as the supreme authority. Al- Qur'an provides the regulations that create the proper relations between man and Allah, man and man. It leads man to understand his role in this world, encourages him to think and ponder, and guides him in the usage of natural resources. Al- Qur'an provides all the guidance that humanity needs. Without the guidance of the Quran, humanity would still be groping in the darkness of ignorance.

"Surely we have sent down the reminder (Al-Quran) and we will most surely be its guardian (Surah Al-Hijr -verse 9)

Al Qur'an is pure revelation of Allah, not of lust sayings of the Prophet Muhammad. Al - Qur'an contains the rules of human life on earth. Al-Qur'an is a guide for those who are faithful and devoted.

In Al- Qur'an there is a great grace and a lesson for those who believe. Al- Qur'an is the holy book of which contains revelation from Allah that was given to the prophet Muhammad SAW. It is the way of life for all humans until the end of time. It orders people to be dignified, modest, trustworthy, kind, faithful, mature and responsive.

describes the way we should walk: "Turn not your face away from men with pride, nor walk in insolence through the earth.

-Fatihah, and closed with a letter An- Nas. Al- Qur'an is the holy book of which contains revelation from Allah that was given to the prophet Muhammad SAW. It is the way of life for all humans until the end of time. It orders people to be dignified, modest, trustworthy, kind, faithful, mature and responsive. Al-Qur'an even describes the way we should walk: "Turn not your face away from men with pride, nor walk in insolence through the earth.

Children, teenagers or parents gathered in mosque on certain days to read Al- Qur'an. Many people who are not good at reading Al-Quran. They sometimes just reading without knowing the meaning and significance that are in surah they have read. And most public schools lack of knowledge in understanding the original meaning very well about Al-Qur'an, because they very rarely do observation measure the ability of understanding Al- Qur'an, and translations of the surah they have read and understood themselves.

Related to phenomena above from the researcher found that fact of phenomena occurring over most of the Muslims themselves, from the our environment and public schools especially in the public schools of Islamic religious education does not understand the meaning contained in the holy book Al- Qur'an with real meaning in Qur'an itself. Although public schools are one religion school of Islam that it contains the teachings of Islam. Muslim society we are less aware about how 
important benefits of the Qur'an in our lives. Our society is not familiar with Islam in depth. So they do not dig more meanings in the Qur'an. Whereas Allah promises plenty of enjoyment for those who learn the Qur'an and the meaning hidden in the Qur'an.

Surah Ar-Rahman has benefits in education, indicates that the properties of educators are generous, compassionate, gentle, polite and morality to their students and anyone (Personal Competence). A teacher should has the competence pedagogy good as God teaches the Al-Qur'an to prophets. Al- Qur'an shows as the material given to the students was the truth or knowledge of God (Professional Competence). The success of an educator was students are able to accepted and develop the education they provide, so that students become the generation that has a spiritual intelligence and intellect.

Ar-Rahman can help us multiply praise God, surrender to God wholeheartedly. Reminds us to be compassion for all creatures of God. Reminds us to be grateful that Allah has given to us. Ar-Rahman reminded us that there are other creatures besides humans who worship God. Ar-Rahman reminded that humans are forgetful by repeating the verses"

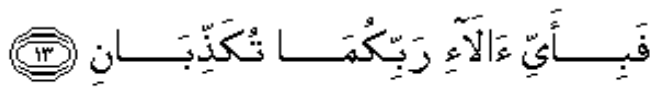

" (Maka nikmat Tuhan kamu yang manakah yang kamu dustakan)

\section{RESEARCH METHOD}

In this research, the researcher used descriptive qualitative research. The researcher want to analyzed a document and the data was taken from Al-Hidayah Al-Quran Tafsir Per Kata TajwidKodeAngka by Kalim, 2011. Meanwhile, the reason why the researcher used qualitative approach in analyzed content of document because according to the researcher this method was appropriated for her study because the researcher want to described about figures of speech used in Surah Ar- Rahman and the data was shown in the sentence. Therefore, the researcher thinks this approach was agreeable to analyzed the Figures of speech in Surah Ar- Rahman.

\section{FINDINGS AND DISCUSSIONS}

Some findings are drawn after analyzed the data deliberately. The findings in this study were formulated as the followed:

1. There were ten kinds of figures of speech used Surah Ar-Rahman, they were: 3 Simile, 2 Personifications, 1 Apostrophe, 31 Repetition, 2 Parallelism, 1 Apophasis, 1 Pleonasm, 1 Prolepsis, 1 Antonomasia, and 1 Tautology. 
2. The way of the used figures of speech in Surah Ar- Rahman were through 1) Explicitly 2) Comparing things 3) Noun 4) Repetition 5) Synonym 6) Denial 7) Redundancy 8) Substitution and 9) Future.

3. The reason used Surah Ar- Rahman in the ways they were: (1) Faith, (2) The Laws of Justice, (3) Man and Jinn, (4) Hell (5) Favors Heaven. In (1) Faith, God teaches man how to speak, grow trees and plants are submissive to the God. All creatures would be destroyed unless the God; God was always in activity, the whole universe was a deliciously gods to humans; man was created from ground and jinn from fire. (2) The Laws of Justice, relating to the obligation measure, weigh with justice. 3) Mann and Jinn, the gods favor the greatest of favors given to man there was Al-Qur'an. Favors that unfolds in nature about the state of the jinn and mankind, the state of doomsday and hell. 4) Hell explain God showed signs of people who will go to hell on the Day of Judgment for not grateful for the blessings that He gave. 5) Favors Heaven explain that God said to the servant who appreciate the pleasure of going to the promised blessings of the Garden and all the facilities are there.

The Discussion aims to discuss the research findings explained in the previous section. It deals with the three research problems namely, what kinds of figures of speech used in surah Ar- Rahman, how are figures of speech used in the surah Ar- Rahman, why figures of speech used in the ways they are. The detail discussions about those problems are elaborated as follows:

Imam (2012) also describe the meanings of figurative language found in the English translation of surah Al-Baqarah by Abdullah Yusuf Ali. The research finding shows that there are 9 similes, 10 metaphors, 30 metonymies, 3 personifications, 5 paradoxes and 27 symbols.

From the research finding, the researcher found ten kinds figures of speech in surah Ar-Rahman. They were: 3 Simile, 2 Personification, 1 Apophasis, 31 Repetition, 2 Parallelism, 1 Apostrophe, 2 Pleonasm, 1 Prolepsis, 1 Antonomasia and 1 Tautology.

Siti (2012) also describing figurative language in surah Maryam. The process to analyze surah Maryam the writers used contextual meaning as a process to know and understand about the contextual meaning each verse that contained stories of Prophet, guidelines and philosophies of life from Allah.

From the research finding, the researcher found the process of surah Ar-Rahman by explicitly, comparing things, noun, repetition, synonym, denial, redundancy, substitution, and future.

Based on Ibnu Katsir Tafseer the reason why figures of speech used in Surah ArRahman are because of five contextual reasons. They are (1) Faith (2) The Laws of Justice, (3) Man and Jinn, (4) Hell (5) Favors Heaven. 


\section{CONCLUSIONS}

After analyzing the data conclusions are drawn as the following:

1) There were ten kinds of figures of speech used Surah Ar-Rahman, they were: 3 Simile, 2 Personifications, 1 Apostrophe, 31 Repetition, 2 Parallelism, 1 Apophasis, 1 Pleonasm, 1 Prolepsis, 1 Antonomasia, and 1 Tautology.

2) The used of figures of speech in Surah Ar- Rahman were through 1) Explicitly 2) Comparing things 3) Noun 4) Repetition 5) Synonym 6) Denial 7) Redundancy 8) Substitution and 9) Future.

3) The reasons using figures of speech were: (1) Faith, (2) The Laws of Justice, (3) Man and Jinn, (4) Hell (5) Favors Heaven. In (1) Faith, God teaches man how to speak, grow trees and plants are submissive to the God. All creatures would be destroyed unless the God; God was always in activity, the whole universe was a deliciously gods to humans; man was created from ground and jinn from fire. (2)The Laws of Justice explain relating to the obligation measure, weigh with justice. 3) Mann and Jinn explain the Gods favor the greatest of favors given to man there was Al-Qur'an. Favors that unfolds in nature about the state of the jinn and mankind, the state of doomsday and hell. 4) Hell explain God showed signs of people who will go to hell on the Day of Judgment for not grateful for the blessings that He gave. 5) Favors Heaven explain that God said to the servant who appreciate the pleasure of going to the promised blessings of the Garden and all the facilities are there.

\section{REFERENCES}

Andriyani, Agustin. 2015 An Analysis of Figure of Speech in William Wordsworth's Selected Poems,Surabaya: UIN SunanAmpel.

Arista, Puspita. 2014 AStylistic Analysis of Figures of Speech in Les Miserables Movie, Yogyakarta: Universitas Yogyakarta.

Arp \& Perrine.1963. Sound and Sense: AP English Literature and Composition. Archishop Moeller English Departement.

Bogdan, Bikken. 1992. Transforming Qualitative Data. New Delhi: Thousand Oaks. 
Chaer, Abdul. 1998. Tata Bahasa Praktis Bahasa Indonesia. Jakarta: PT Rineka Cipta.

Chierchia, G. \& Connal, A. 1990. Meaning and Grammar. Massachusetts: Massachusetts Institute and Technology.

Creswell, J.W. 1998. Qualitative Inquiry and Research Design Second Edition. CA: Sage Publications.

Denzin. N.K.1970. The Research Act in Sociology, Chicago: Aldine. Retrievedfrom(Http//referenceworld.com/sage/socialscience/triangulation.pdf.).

Hannifah, Tutuk S. 2014 The Study Of Figures Of Speech In Maher Zein's Songs, Surabaya: UIN Sunan Ampel.

Henry,Guntur. 2004. Pengajaran Gaya Bahasa,. Bandung: Angkasa.

Katsir, I.1994.Lubaabut Tafsir min Ibni Katsir ( Tafsir Ibnu Katsir.Jakarta: Celbrige

Keraf, Gorys.2004. Diksi dan Ragam Bahasa. Jakarta: Gramedia Pustaka

Lincoln, YS \& Guba, EG.1985. Naturalistic Inquiry. Newbury Park, CA: Sage Publications.

Masruri, Muh 2012. Figurative Language Analysis in Letto's Song' Truth, cry and lie' Album. Salatiga: State Institu for Islamic Studies (STAIN).

Miles, M.B and Huberman, A.M, \& Saldana. 2014. Qualitative Data Analysis: A Method of Source Book. $3^{\text {th }}$ Edition.: USA: Sage Publication

Partini. 2010. A Pragmatic Analysis On Figurative Language Used In English Translation Of Al-Quran Chapter Al-Baqarah. Skripsi thesis, Universitas Muhammadiyah Surakarta

Peter. 2002.Figurative Language and Semantics,pps.12. Boston : Little Brown and Company

Rizal, Muhammad. 2013. Figurative Languages Found in English Translation of Al-Qurâan Surah Al-Hajj. Pendidikan Bahasa Inggris Universitas Muhammadiyah Purworejo. Vol 1, No 3 (2013): English Research Articles

Rosyida, Kholifah.2011. The Using of Figurative Language in Confession of A Shopaholic Movie. Salatiga: State Institute For Islamic Studied ( STAIN). 
Siti, Anita. 2012 Figurative Language Used In Yusuf Ali's English Translation of Surah Maryam.Iain Tulungangung.

Surianto. 2010.An Analysis of Lexical Relation of the 30th Section of Holy Quran Translated by Abdullah Yusuf Ali." Unpublished Thesis. Faculty of Letters. Medan: University of Sumatera Utara.

Sutadi.2013. An Analysis of Lexical Relations in Abdullah Yusuf Ali's Translation of Surah Ya-Sin of the Holy Qur'an.Unpublished Thesis. Faculty Of Adab And Cultural Sciences State Islamic University Sunan Kalijaga Yogyakarta

Thompson, Neil. 2003. Communication and language: A handbook of Theory and Practice. Palgrave Macmillan.

Tirajoh, Juliana. 1988. English Poetry: An Introduction to Indonesia Students. Jakarta: Departemen Pendidikan dan Kebudayaan.

Tripathy, Anjali. 2014. Research Journal of English Language in Literature.

Webster, Mariam.2004. The New Lexicon Webster's Dictionary of The English Language. USA: Lexicon Publication.INC.

Wren \& Martin. 1995. English Grammar and Composition. New Dehli: S. Chand \& Company LTD. 